\title{
Severe COVID-19 is associated with sustained biochemical disturbances and prolonged symptomatology; A retrospective single-centre cohort study

\author{
${ }^{1,2}$ Marija Simjanoska, ${ }^{2}$ Zan Mitrev, ${ }^{3}$ Gianluca Villa, ${ }^{4}$ Daniel O. Griffin, ${ }^{2}$ Rodney A. Rosalia
} \\ ${ }^{1}$ Columbia University, New York, United States \\ ${ }^{2}$ Zan Mitrev Clinic, Department of Clinical Research, Skopje, the Republic of North Macedonia \\ ${ }^{3}$ Department of Health Science, Section of Anaesthesiology and Intensive Care, University of Florence, Florence \\ ${ }^{4}$ Department of Medicine, Division of Infectious Diseases, Columbia University, College of Physicians and Surgeons, New York NY, USA; ProHealth, an OPTUM Company, NY Lake Success, New York, USA.
}

Running title: Long-COVID is associated with sustained biochemical disturbances

Number of Tables: 3

Number of Figures: 3

Word count: 2699

Mariija Simjanoska: m.simjanoska@columbia.edu

Zan Mitrev: zan@zmc.mk

Gianluca Villa: gianluca.villa@unifi.it

Daniel O Griffin: dg2810@cumc.columbia.edu

Rodney Rosalia: rodney.rosalia@zmc.mk

Keywords: Tail phase - SARS-CoV-2 - Long COVID - Coagulopathy - Hyper Inflammation

\section{Correspondence:}

Dr Rodney Rosalia, PhD

Zan Mitrev Clinic

Bledski Dogovor 8, Skopje 1000, The Republic of North Macedonia

Telephone: +38971305957

E-mail address: rodney.rosalia@zmc.mk 


\section{Abstract}

Introduction: Coronavirus disease 2019 (COVID-19) is associated with significant acute clinical manifestations, and reports indicate that some patients experience prolonged symptomatology and morbidity. These late clinical manifestations have been termed Post-Acute Sequelae of COVID-19 (PASC) and hypothesised to be associated with clinical severity in the acute infection phase and biochemical abnormalities.

Aim: Evaluate the incidence of PASC in previously hospitalised COVID-19 patients and compare the admission and follow-up levels of biochemical parameters stratified according to baseline clinical severity. Methods: $\mathrm{N}=168$ COVID-19 patients previously hospitalised at the Zan Mitrev Clinic in Skopje, North Macedonia, with matched laboratory data at baseline and follow-up clinical visit $>30$ days post-discharge, were stratified according to National Institute of Health clinical severity guidelines as mild, moderate, severe or critical according to admission clinical presentation. We assessed the incidence of PASC and compared the biochemical profile.

Results: The median hospitalisation and clinical follow-up period were 11 (9-20) and 53 (30-105) days. The overall incidence of PASC was 56.5\% (95/168); most PASC cases were confined to the severe subgroup (61/101, 61.4\%). Contrary to mild and moderate cases and a healthy "non-COVID-19" control cohort, we observed that severe COVID-19 cases experienced sustained biochemical disturbances, most notably elevated D-dimers and Ferritin of $600 \mathrm{ng} / \mathrm{ml}$ (283-1168) and $432 \mathrm{ng} / \mathrm{ml}$ (170-916), respectively.

Conclusions: Previously hospitalised severe COVID-19 patients are more likely to experience Post-Acute Sequelae of COVID-19 and prolonged biochemical disturbances, evident by abnormal values of D-dimers and Ferritin. 


\section{Introduction}

Coronavirus disease 2019 (COVID-19), caused by severe acute respiratory syndrome coronavirus 2 (SARS-CoV-2), is marked by several pathological mechanisms ${ }^{1}$ and clinical severity phases ${ }^{2}$ leading to acute morbidity and mortality ${ }^{3}$. Published studies have elucidated many underlying inflammatory pathologies and coagulopathies that characterise acute infection and the early clinical manifestations ${ }^{4-6}$.

COVID-19 disease may be stratified into five phases $^{7}$ : viral symptom phase, early inflammatory phase, secondary infection phase, multisystem inflammatory phase, and tail phase; the latter characterises disease features experienced beyond 30 days of infection.

Studies $^{8-10}$ show that a substantial proportion of recovered patients experience persistent clinical symptoms during the tail phase of the disease, most commonly fatigue, dyspnoea, and impaired pulmonary function ${ }^{11}$ 12. These Post-Acute Sequelae of COVID-19 (PASC) have been termed "Long COVID" or "Post-COVID-19 Syndrome" and are found to be more prevalent among hospitalised patients with severe disease $\mathrm{e}^{13-15}$.

Most research has focused primarily on describing the nature of the PASC experienced by recovered patients $^{4}$; however, the biochemical disturbances observed in the tail phase of COVID-19 are ill-defined. Understanding the long-term impact of COVID-19 according to routine laboratory biomarkers may support clinical decision making and help construct appropriate treatment strategies and rehabilitation approaches. This study evaluates the incidence of PASC and leverages a panel of 22 laboratory parameters to estimate the patient biochemical profile two months post-infection stratified to baseline clinical severity. 


\section{Methods}

\section{Study design and data sources}

In this retrospective single-centre cohort study, we screened all adult patients admitted at the Zan Mitrev Clinic, Skopje, North Macedonia, between June 2020 and June 2021 with confirmed COVID-19, ICD-10CM U07.1 and ICD-10-CM U07.2. The study design and cohort are presented in the Strengthening the Reporting of Observational Studies (STROBE) diagram (Figure 1).

We excluded patients hospitalised for less than 72 hours and evaluated recovered patients successfully discharged following treatment who presented for follow-up assessment, including blood biochemistry evaluation.

The patient cohort was stratified according to the clinical presentation at admission in severity groups as per $\mathrm{NIH}$ guidelines ${ }^{16}$, namely mild, moderate, severe and critical.

We considered cases with follow up data until the $19^{\text {th }}$ of August 2021; the last patient admitted during the country's $3^{\text {rd }}$ COVID-19 surge was on the $8^{\text {th }}$ of June. Cases with laboratory data at admission and postCOVID (defined as laboratory data $\geq 30$ days post-hospital admission) were considered eligible for the study. Clinical symptomatology was recorded at the most recent follow-up visit. We used the median value for subsequent comparative analysis for individuals with multiple laboratory analyses performed after $\geq 30$ days.

Laboratory, clinical, and sociodemographic data were extracted from electronic health records. To account for local, demographic, genetic, nutritional and environmental factors ${ }^{17}$ we established reference values using laboratory results from self-reported healthy individuals undergoing routine annual check-ups at our clinic. 


\section{Statistical analysis}

Patient clinical characteristics are presented as median + interquartile range (IQR) or mean \pm standard deviation (SD) for continuous variables and absolute values with corresponding percentages for categorical variables.

Continuous variables were evaluated for normality using the Shapiro-Wilk test, and non-parametric tests were selected when at least one group followed a non-Gaussian distribution. The Chi-square or Fisher`s exact test were used to assess the association between categorical variables, clinical severity or PASC. Comparisons of admission versus follow-up data were performed using Wilcoxon matched-pairs signedrank test. Kruskal-Wallis and Dunn's multiple comparisons tests were used to assess differences across the three clinical severity groups at admission and follow-up.

Follow-up blood biochemistry values were compared to reference values using a Mann-Whitney test. Comparative results are reported according to their "effect size" (Median/Mean differences $+95 \%$ Confidence Interval, Odds ratio (OR), and Etas squared when appropriate).

\section{Biochemistry Analysis}

Biochemistry analyses were performed as previously described ${ }^{18}$. Diagnosis of SARS-CoV-2 infection was defined as a positive outcome to RT-PCR from nasal/oral swab.

\section{Ethical considerations}

The present study was approved by the local Ethics Committee of the Zan Mitrev Clinic. As an observational study, enrolled patients did not receive additional medical, pharmacological or behavioural interventions other than those administered in routine clinical practice, [\#EBPZ.357, NCT04478539].

This research study was conducted in accordance with the principles laid out in the original Declaration of Helsinki. Written informed or verbal consent was obtained from all patients for publication of this manuscript under condition of full anonymity; the use of all health and medical information for scientific research and manuscript preparation was approved. For those patients that were not traceable, the need for informed consent was waived by the ethical committee. 


\section{Results}

\section{Patient demographics and clinical characteristics at admission}

We hospitalised 1063 patients with confirmed COVID-19 disease at Zan Mitrev Clinic between June 2020 and June 2021. The study cohort details are presented in Figure 1. Most of our patients were from Skopje or referred from peripheral clinics across North Macedonia and Kosovo (Supplemental Figure 1A).

The study cohort $(\mathrm{N}=168)$ - with a median age of $59(50-68)$ years of which $75 \%$ were male (Table 1) was stratified into subgroups according to National Institute of Health $(\mathrm{NIH})$ clinical severity stratification and treatment guidelines ${ }^{16}$ into mild $(N=38,23 \%)$, moderate $(N=29,17 \%)$ and severe $(N=101,60 \%)$.

The clinical and demographic profiles of the study cohort and subgroups are shownin Table 1. Subgroups were similar in terms of age, gender proportion, and comorbidity distribution.

The peripheral oxygen saturation $\left(\mathrm{SpO}_{2} \%\right)$, cut-off $<94 \%$, represents a key variable for severity stratification. Further translation of the NIH classification to clinical practice showed that moderate cases would either be admitted on- or required supplementary oxygen (flow rates of $2-15 \mathrm{~L} / \mathrm{min}$ ). Severe cases were characterised by a higher oxygen dependence, continuous positive airway pressure (CPAP) or the need for intubation and mechanical respiratory support during the clinical course.

The "severe" subgroup included one critical patient ${ }^{19}$ admitted with respiratory and multi-organ failure and discharged after 49 ICU days.

We detected pathological levels for several biomarkers at admission and observed that these biochemical disturbances tended to correlate with clinical severity. For instance, levels of Interleukin 6 (IL-6), C-Reactive Protein (CRP), D-dimers, LDH and Ferritin in severe cases were on average 1.5 to 2.3 -fold higher compared to mild or moderate cases (Supplemental Table 1 and 2). 
medRxiv preprint doi: https://doi.org/10.1101/2021.09.02.21262599; this version posted September 7, 2021. The copyright holder for this preprint (which was not certified by peer review) is the author/funder, who has granted medRxiv a license to display the preprint in perpetuity.

All rights reserved. No reuse allowed without permission.

\section{Clinical course and acute treatment}

Respiratory distress is one of the hallmarks of COVID-19; viral propagation may lead to lung tissue injury, pneumonia, and impaired lung functioning. To that end, oxygen support forms a cornerstone of COVID-19 treatment; 90 (54\%) patients were admitted on or required supplemental oxygen in the first 24 hours, median $4 \mathrm{~L} / \min (2-10)$. Another 24 patients (15\%) required non-invasive mechanical ventilation within the first 24 hours of admission - these patients were placed on CPAP at a median of $80 \%(60-100)$ fraction of inspired oxygen (Table 2). Nevertheless, we observed disease progression in 7 mild to- moderate and 12 severe cases, ultimately leading to ICU admission, intubation and mechanical respiratory support during the clinical course.

Moderate and severe cases received dexamethasone, typically a 10-day course of $6 \mathrm{mg}$ once daily; critical cases or other patients showing signs of hyper inflammation were treated with intravenous dexamethasone at a dose of $8 \mathrm{mg}$ q.d.

Secondary infections are recognised as acommon complication of hospitalised COVID-19 patients. We recorded 58 (35\%) cases of bacterial infections occurring a median of 13 (5-32) days after admission. The majority of bacterial infections were caused by Enterococcus (21\%), Acinetobacter Baumannii (13\%) and Escherichia Coli (11\%) (Supplemental Figure 2). Fungal infections were also prevalent in our COVID-19 cohort; we observed 57 cases (34\%) of secondary infections with Candida species occurring a median of $1.5(0-12)$ days after admission.

Finally, total hospitalisation increased on average by 2 days according to the disease severity (Table 2); the median hospitalisation time for severe cases was 13 (10-21) days. 
medRxiv preprint doi: https://doi.org/10.1101/2021.09.02.21262599; this version posted September 7, 2021. The copyright holder for this preprint (which was not certified by peer review) is the author/funder, who has granted medRxiv a license to display the preprint in perpetuity.

All rights reserved. No reuse allowed without permission.

\section{COVID-19 symptomatology and biomarker profile at follow-up}

Patients were encouraged to attend follow-up laboratory analyses and clinical examinations at least once every 3 months; $20.9 \%$ (168 out of 805 ) of the patients complied with our recommendations resulting in a median follow-up time of 53 (30-105) days; follow-up compliance was similar across the sub-groups (Table 2). PASC was reported by 95 patients (56.5\%), of which severe patients represented most cases experiencing long-term symptoms, 60.4\% (61/101). We observed increasing cases of PASC associated with clinical severity, but the Chi-square test for trend was non-significant (Figure 2). Individuals experiencing PASC most commonly reported "Tiredness or fatigue", "Difficulty breathing or shortness of breath", and "Heart palpitations" as primary ailments.

We next assessed biochemical profiles in each subgroup; we observed that laboratory abnormalities seen in mild and moderate COVID-19 patients during their hospital stay typically resolved within the follow-up period (Table 3) except for D-dimers that remained slightly elevated.

In contrast, patients hospitalised with the severe disease showed sustained disturbances of several biomarkers at follow-up (Table 3, Figure 3).

Notably, severe cases presented with elevated, Ferritin 432 ng/mL (170-916), D-dimer 600 ng/ml (2831168) and to a lesser extent, LDH, 243 U/L (206-346), C-Reactive Protein (CRP) 5.7 mg/L (2.5-18.9) and IL-6, $5.1 \mathrm{pg} / \mathrm{ml}$ (1.7-28.9) (Table 3). Severe cases also exhibited disruptions in white blood cell indices at follow-up; the Neutrophil-to-Lymphocyte ratio (NLR) and Systemic Immune Inflammation index (SII) were elevated on average by $0.4[95 \% \mathrm{Cl} 0.06$ to 0.5$]$ and 114 [95\% $\mathrm{Cl} 28.7-147]$ compared to the control population.

Collectively, these results show that more than half of hospitalised COVID-19 report long-term symptoms and everyday ailments. Moreover, severe COVID-19 cases also present with prolonged biochemical disturbances and disruption of immune homeostasis. 


\section{Discussion}

COVID-19 disease caused by SARS-CoV-2 is an international public health emergency because of the significant mortality in the early inflammatory disease phase ${ }^{7}$. This study builds on recent observations of prolonged morbidity and frailty in the tail phase of the disease (> 30 days post-infection), termed Post-Acute Sequelae of COVID-19 (PASC) ${ }^{7}$.

In this observational study, we report the incidence of PASC by clinical disease severity in a previously hospitalised COVID-19 cohort in Skopje, North Macedonia. Secondly, we estimated the extent of postdischarge biochemical disturbances in each subgroup by assessing deviations from reference values generated from a healthy control cohort of non-COVID patients attending the outpatient clinic for their annual check-up.

Disease classification at admission represents a "snapshot", an attractive starting point for comparative and association analyses. To that end, we observed notable differences in biochemical profile and PASC with increasing disease severity. However, COVID-19 is notorious for its unpredictable clinical course; some individuals experienced acute worsening and adverse outcomes following admission. Nonetheless, we also observed remarkable cases of clinical recovery from severe disease leading to independence from supplemental oxygen and hospital discharge; the latter group formed the basis for the study cohort and long-term observation.

Residual symptomatology of SARS-CoV-2 infection was observed in $56.5 \%$ of patients, comparable to the findings of previous studies ${ }^{11} 20-22$. There were no major differences in PASC according to baseline severity - despite a trend, the correlation between PASC rates and severe disease did not reach statistical significance.

In contrast, follow-up laboratory data suggests a sustained disruption of biochemical, immunological and coagulation pathways most apparent in the severe subgroup. Particularly, Ferritin, D-dimers, and to an extent LDH, IL-6 and CRP remained abnormal in severe cases up to 38 (24-75) days after discharge (Table 3).

These observations hold true when compared to mild- to moderate COVID-19 cases but also a healthy control cohort; collectively, the results show that severe SARS-CoV-2 infection triggers prolonged disruption of host homeostasis. 
We conclude that the pathological mechanisms driving severe disease in the viral symptom and early inflammatory phase (Supplemental Table 1 and 2) may persist long after discharge in select individuals. We observed a trend between COVID-19 coagulopathy and early clinical severity. Elevated levels of Ddimer and fibrin/fibrinogen degradation products were observed in our cohort during hospitalisation (Table 3) as reported by others ${ }^{23}$, with D-dimer levels selected to differentiate between severe and mild cases ${ }^{24}{ }^{25}$. Interestingly, at follow-up, sustained abnormal D-dimer levels were observed in the presence of normalised fibrinogen levels, and platelet counts similar to previous findings ${ }^{26-28}$.

Ferritin was substantially increased at admission and follow-up, particularly in severe cases (Supplemental

Table 1 and 2). This marker is an established independent prognostic factor for clinical severity in COVID19 patients $^{29}{ }^{30}$, and recent literature ${ }^{31}$ suggests that unbound iron may play a role in the inflammation and hypercoagulation (= $\uparrow$ D-dimers) found in severe COVID-19.

Frequently observed comorbidities, such as hypertension (48\%) and Type II Diabetes (18\%), may also contribute to the inflammatory cycle $\mathrm{e}^{32}$ and further disrupt interconnected coagulation pathways ${ }^{33}$.

Residual lung tissue injury and delayed repair ${ }^{34}$ might explain the, to an extent, sustained LDH levels at follow-up; recent work found that severe patients who required prolonged hospitalisation ( $\geq 17$ days) were more prone to suffer from long-term tissue damage and persistent post-COVID-19 symptomatology 35 .

Furthermore, severe cases were characterised by critically low levels of $\mathrm{SpO}_{2} \%, 88 \%$ (80-92), a need for respiratory support and on average 4 more hospitalisation days than mild cases. This early stage of (peripheral) hypoxia may induce chronic inflammation independent of viral antigens ${ }^{32}$. In addition, severe cases presented a more pronounced inflammatory profile than the mild and moderate subgroups (Supplemental Table 2). At follow-up, low-grade inflammation seemed persistent, indicated by comparatively elevated CRP and IL-6 levels (Table 3).

Our observations resonate with Liao et al. ${ }^{27}$, who reported elevated levels of IL-6 and other proinflammatory cytokines in mainly severe cases at weeks 4 and 6 post-discharge. Moreover, the authors established an association between sustained IL-6 levels and persistent pulmonary lesions.

In a comparable time window after discharge, Mandal and colleagues ${ }^{36}$ found that a proportion of patients experienced persistently elevated D-dimer and CRP serum concentrations. 
These homeostatic disruptions may function synergistically in severe cases; hence, returning to homeostasis is slower, resulting in prolonged symptomatology known as "Long COVID".

The incidence of bacterial co-infection (35\%) is higher than in published studies ${ }^{37-39}$. Admittedly, our clinical team faced unprecedented challenges adhering to local antimicrobial stewardship protocols and international COVID-19 treatment guidelines. Empirical antibiotics were administered for a maximum of 48 hours or discontinued immediately following negative representative cultures ${ }^{40}$; however, unwarranted antibiotic prophylaxis is unfortunately still common clinical practice in the Western Balkans ${ }^{41-44}$.

Moreover, the administration of the immunosuppressant dexamethasone, known to disrupt the innate and adaptive immune responses and increase susceptibility to invasive fungal diseases ${ }^{45-47}$, may explain the early and high incidence of fungal co-infection in our cohort. As reported previously, the proportion of fungal and bacterial co-infections was the highest in severe COVID-19 cases $^{4849}$.

\section{Limitations}

The study's observational single-centre design prevents us from establishing a causative relationship between initial disease severity, presence of PASC, and degree of biochemical disturbances. Follow-up visits to our clinic were affected by ongoing lockdowns and public movement restrictions. As a result, we lacked exhaustive follow-up data on the whole "survivors cohort". Consequently, certain analyses were underpowered due to the sample size and we were unable to connect the reported PASC rates with the observed biochemical profiles.

Nonetheless, this study presents time-series matched data acquired from the clinic's Electronic Health Records and Laboratory Information System, excluding interlaboratory variations. Of importance, the clinical characteristics and biochemical profile of the study cohort $(N=168)$ were representative of the whole cohort $(\mathrm{N}=1063)$ (Supplemental Table 3), suggesting that minimal impact on the results related to bias in the study design. Furthermore, comparison to a local reference values accounts for the many factors that affect biochemical pathways - hence, we were able to more accurately estimate deviations from normal values.

To the best of our knowledge, the current work is one of the first to report a matched admission vs followup biochemical profile according to NIH severity status guidelines, thus providing real-world insights into Long COVID-19 biochemical disturbances. 
medRxiv preprint doi: https://doi.org/10.1101/2021.09.02.21262599; this version posted September 7, 2021. The copyright holder for this preprint (which was not certified by peer review) is the author/funder, who has granted medRxiv a license to display the preprint in perpetuity.

All rights reserved. No reuse allowed without permission.

\section{Conclusion}

This study contributes to the emerging literature on the "Post-Acute Sequelae of COVID-19" phase of COVID-19. We show that whereas mild- and moderate cases recover biochemical homeostasis after discharge, severe cases are characterised by a higher incidence of PASC as well as sustained biochemical disturbances such as elevated D-dimers, Ferritin, LDH, CRP, IL-6 and immune indices NLR and SII; features commonly observed with low-grade inflammation in the elderly population, "inflammaging" 50-54. Our findings suggest that an initial evaluation and a time-series analysis of biochemical markers may aid in the diagnosis, risk stratification, construction of individualised rehabilitation approaches, clinical management, and a better understanding of the mechanism driving PASC. 
medRxiv preprint doi: https://doi.org/10.1101/2021.09.02.21262599; this version posted September 7, 2021. The copyright holder for this preprint (which was not certified by peer review) is the author/funder, who has granted medRxiv a license to display the preprint in perpetuity.

All rights reserved. No reuse allowed without permission.

\section{References}

1. Wiersinga WJ, Rhodes A, Cheng AC, et al. Pathophysiology, Transmission, Diagnosis, and Treatment of Coronavirus Disease 2019 (COVID-19): A Review. JAMA 2020;324(8):78293. doi: 10.1001/jama.2020.12839

2. Jesenak M, Brndiarova M, Urbancikova I, et al. Immune Parameters and COVID-19 Infection - Associations With Clinical Severity and Disease Prognosis. Frontiers in Cellular and Infection Microbiology 2020;10(364) doi: 10.3389/fcimb.2020.00364

3. Figliozzi S, Masci PG, Ahmadi N, et al. Predictors of adverse prognosis in COVID-19: A systematic review and meta-analysis. Eur J Clin Invest 2020;50(10):e13362. doi: 10.1111/eci.13362 [published Online First: 2020/07/30]

4. Yang L, Liu S, Liu J, et al. COVID-19: immunopathogenesis and Immunotherapeutics. Signal Transduction and Targeted Therapy 2020;5(1):128. doi: 10.1038/s41392-020-00243-2

5. Choudhary S, Sharma K, Silakari O. The interplay between inflammatory pathways and COVID-19: A critical review on pathogenesis and therapeutic options. Microbial Pathogenesis 2021;150:104673. doi: https://doi.org/10.1016/j.micpath.2020.104673

6. Kander T. Coagulation disorder in COVID-19. Lancet Haematol 2020;7(9):e630-e32. doi: 10.1016/s2352-3026(20)30218-0 [published Online First: 2020/07/14]

7. Griffin DO, Brennan-Rieder D, Ngo B, et al. The Importance of Understanding the Stages of COVID-19 in Treatment and Trials. AIDS Rev 2021:23(1):40-47. doi: 10.24875/AIDSRev.200001261 [published Online First: 2021/02/09]

8. Ayoubkhani D, Khunti K, Nafilyan V, et al. Post-covid syndrome in individuals admitted to hospital with covid-19: retrospective cohort study. BMJ 2021;372:n693. doi: 10.1136/bmj.n693

9. Romero-Duarte Á, Rivera-Izquierdo M, Guerrero-Fernández de Alba I, et al. Sequelae, persistent symptomatology and outcomes after COVID-19 hospitalization: the ANCOHVID multicentre 6-month follow-up study. BMC Medicine 2021;19(1):129. doi: 10.1186/s12916-021-02003-7

10. Huang C, Huang L, Wang Y, et al. 6-month consequences of COVID-19 in patients discharged from hospital: a cohort study. Lancet 2021;397(10270):220-32. doi: 10.1016/s0140-6736(20)32656-8 [published Online First: 2021/01/12]

11. Halpin SJ, Mclvor C, Whyatt G, et al. Postdischarge symptoms and rehabilitation needs in survivors of COVID-19 infection: A cross-sectional evaluation. J Med Virol 2021;93(2):1013-22. doi: 10.1002/jmv.26368 [published Online First: 2020/07/31]

12. Goërtz YMJ, Van Herck M, Delbressine JM, et al. Persistent symptoms 3 months after a SARS-CoV-2 infection: the post-COVID-19 syndrome? ERJ Open Research 2020;6(4):00542-2020. doi: 10.1183/23120541.00542-2020

13. Carfi A, Bernabei R, Landi F. Persistent Symptoms in Patients After Acute COVID-19. Jama 2020;324(6):603-05. doi: 10.1001/jama.2020.12603 [published Online First: 2020/07/10]

14. Salamanna F, Veronesi F, Martini L, et al. Post-COVID-19 Syndrome: The Persistent Symptoms at the Post-viral Stage of the Disease. A Systematic Review of the Current Data. Frontiers in Medicine 2021;8(392) doi: 10.3389/fmed.2021.653516

15. Nalbandian A, Sehgal K, Gupta A, et al. Post-acute COVID-19 syndrome. Nature Medicine 2021;27(4):601-15. doi: 10.1038/s41591-021-01283-z

16. National Institutes of Heath. Clinical Spectrum | COVID-19 Treatment Guidelines: @NIHCOVIDTxGuide; 2021 [Available from: https://www.ncbi.nlm.nih.gov/pubmed/.

17. Ouma JO, Mulama DH, Otieno L, et al. Clinical laboratory hematology reference values among infants aged 1month to 17 months in Kombewa Sub-County, Kisumu: A cross sectional study of rural population in Western Kenya. PloS one 2021;16(3):e0244786. doi: 10.1371/journal.pone.0244786 
medRxiv preprint doi: https://doi.org/10.1101/2021.09.02.21262599; this version posted September 7, 2021. The copyright holder for this preprint (which was not certified by peer review) is the author/funder, who has granted medRxiv a license to display the preprint in perpetuity.

All rights reserved. No reuse allowed without permission.

18. Rosalia RA, Ugurov P, Neziri D, et al. Extracorporeal Blood Purification in Moderate and Severe COVID-19 Patients: A Prospective Cohort Study. Blood Purification 2021 doi: $10.1159 / 000515627$

19. Rieder M, Zahn T, Benk C, et al. Cytokine adsorption in a patient with severe coronavirus disease 2019 related acute respiratory distress syndrome requiring extracorporeal membrane oxygenation therapy: A case report. Artificial Organs;n/a(n/a) doi: 10.1111/aor.13805

20. Moreno-Pérez O, Merino E, Leon-Ramirez J-M, et al. Post-acute COVID-19 syndrome. Incidence and risk factors: A Mediterranean cohort study. Journal of Infection 2021;82(3):378-83. doi: 10.1016/j.jinf.2021.01.004

21. Jacobs LG, Gourna Paleoudis E, Lesky-Di Bari D, et al. Persistence of symptoms and quality of life at 35 days after hospitalization for COVID-19 infection. PLOS One 2020;15(12):e0243882. doi: 10.1371/journal.pone.0243882 [published Online First: 2020/12/12]

22. Garrigues E, Janvier P, Kherabi Y, et al. Post-discharge persistent symptoms and healthrelated quality of life after hospitalization for COVID-19. J Infect 2020;81(6):e4-e6. doi: 10.1016/j.jinf.2020.08.029 [published Online First: 2020/08/28]

23. Iba T, Levy JH, Levi M, et al. Coagulopathy in COVID-19. Journal of Thrombosis and Haemostasis 2020;18(9):2103-09. doi: https://doi.org/10.1111/jth.14975

24. Yao Y, Cao J, Wang Q, et al. D-dimer as a biomarker for disease severity and mortality in COVID-19 patients: a case control study. Journal of Intensive Care 2020;8(1):49. doi: 10.1186/s40560-020-00466-z

25. Yu H-H, Qin C, Chen M, et al. D-dimer level is associated with the severity of COVID-19. Thromb Res 2020;195:219-25. doi: 10.1016/j.thromres.2020.07.047 [published Online First: 2020/07/27]

26. Townsend L, Fogarty H, Dyer A, et al. Prolonged elevation of D-dimer levels in convalescent COVID-19 patients is independent of the acute phase response. Journal of Thrombosis and Haemostasis 2021;19(4):1064-70. doi: https://doi.org/10.1111/jth.15267

27. Liao B, Liu Z, Tang L, et al. Longitudinal clinical and radiographic evaluation reveals interleukin-6 as an indicator of persistent pulmonary injury in COVID-19. International Journal of Medical Sciences 2021;18(1):29-41. doi: 10.7150/ijms.49728

28. Marvisi M, Ferrozzi F, Balzarini L, et al. First report on clinical and radiological features of COVID-19 pneumonitis in a Caucasian population: Factors predicting fibrotic evolution. International Journal of Infectious Diseases 2020;99:485-88. doi: 10.1016/j.ijid.2020.08.054

29. Lin Z, Long F, Yang $Y$, et al. Serum ferritin as an independent risk factor for severity in COVID-19 patients. Journal of Infection 2020;81(4):647-79. doi: 10.1016/j.jinf.2020.06.053

30. Gómez-Pastora J, Weigand M, Kim J, et al. Hyperferritinemia in critically ill COVID-19 patients - Is ferritin the product of inflammation or a pathogenic mediator? Clinica Chimica Acta 2020;509:249-51. doi: https://doi.org/10.1016/j.cca.2020.06.033

31. Habib HM, Ibrahim S, Zaim A, et al. The role of iron in the pathogenesis of COVID-19 and possible treatment with lactoferrin and other iron chelators. Biomedicine \& Pharmacotherapy 2021;136:111228. doi: https://doi.org/10.1016/j.biopha.2021.111228

32. Eltzschig HK, Carmeliet P. Hypoxia and Inflammation. New England Journal of Medicine 2011;364(7):656-65. doi: 10.1056/NEJMra0910283

33. Brotman DJ, Segal JB, Jani JT, et al. Limitations of D-dimer testing in unselected inpatients with suspected venous thromboembolism. The American Journal of Medicine 2003;114(4):276-82. doi: 10.1016/S0002-9343(02)01520-6

34. Henry BM, Aggarwal G, Wong J, et al. Lactate dehydrogenase levels predict coronavirus disease 2019 (COVID-19) severity and mortality: A pooled analysis. The American 
medRxiv preprint doi: https://doi.org/10.1101/2021.09.02.21262599; this version posted September 7, 2021. The copyright holder for this preprint (which was not certified by peer review) is the author/funder, who has granted medRxiv a license to display the preprint in perpetuity.

All rights reserved. No reuse allowed without permission.

Journal of Emergency Medicine 2020;38(9):1722-26. doi:

https://doi.org/10.1016/j.ajem.2020.05.073

35. Han X, Fan Y, Alwalid O, et al. Six-month Follow-up Chest CT Findings after Severe COVID-19 Pneumonia. Radiology 2021;299(1):E177-e86. doi:

10.1148/radiol.2021203153 [published Online First: 2021/01/27]

36. Mandal S, Barnett J, Brill SE, et al. 'Long-COVID': a cross-sectional study of persisting symptoms, biomarker and imaging abnormalities following hospitalisation for COVID-19. Thorax 2021;76(4):396-98. doi: 10.1136/thoraxjnl-2020-215818

37. Nori P, Cowman K, Chen V, et al. Bacterial and fungal coinfections in COVID-19 patients hospitalized during the New York City pandemic surge. Infect Control Hosp Epidemiol 2021;42(1):84-88. doi: 10.1017/ice.2020.368 [published Online First: 2020/07/24]

38. Lansbury L, Lim B, Baskaran V, et al. Co-infections in people with COVID-19: a systematic review and meta-analysis. J Infect 2020;81(2):266-75. doi: 10.1016/j.jinf.2020.05.046 [published Online First: 2020/05/31]

39. Rawson TM, Moore LSP, Zhu N, et al. Bacterial and Fungal Coinfection in Individuals With Coronavirus: A Rapid Review To Support COVID-19 Antimicrobial Prescribing. Clin Infect Dis 2020;71(9):2459-68. doi: 10.1093/cid/ciaa530 [published Online First: 2020/05/03]

40. Adler H, Ball R, Fisher M, et al. Low rate of bacterial co-infection in patients with COVID-19. The Lancet Microbe 2020;1(2):e62. doi: 10.1016/S2666-5247(20)30036-7

41. Versporten A, Bolokhovets G, Ghazaryan L, et al. Antibiotic use in eastern Europe: a crossnational database study in coordination with the WHO Regional Office for Europe. The Lancet Infectious diseases 2014;14(5):381-7. doi: 10.1016/s1473-3099(14)70071-4 [published Online First: 2014/03/25]

42. Horvat O, Mijatović V, Milijasević B, et al. Are There Striking Differences in Outpatient Use of Antibiotics Between South Backa District, Serbia, and Some Scandinavian Countries? Frontiers in public health 2018;6:91. doi: 10.3389/fpubh.2018.00091 [published Online First: 2018/04/14]

43. Jakupi A, Raka D, Kaae S, et al. Culture of antibiotic use in Kosovo - an interview study with patients and health professionals. Pharmacy practice 2019;17(3):1540. doi: 10.18549/PharmPract.2019.3.1540 [published Online First: 2019/10/09]

44. Susan van den Hof SWJMKKIWDLFWSNMGOKAT. Central Asian and European Surveillance of Antimicrobial Resistance. Annual report 2019. 2019 doi: https://www.euro.who.int/en/health-topics/disease-prevention/antimicrobialresistance/publications/2019/central-asian-and-european-surveillance-of-antimicrobialresistance.-annual-report-2019

45. Ezeokoli OT, Gcilitshana O, Pohl CH. Risk Factors for Fungal Co-Infections in Critically III COVID-19 Patients, with a Focus on Immunosuppressants. Journal of Fungi $2021 ; 7(7): 545$.

46. Nasir N, Rehman F, Omair SF. Risk factors for bacterial infections in patients with moderate to severe COVID-19: A case-control study. Journal of medical virology 2021;93(7):456469. doi: 10.1002/jmv.27000 [published Online First: 2021/04/15]

47. Armstrong-James D, Youngs J, Bicanic T, et al. Confronting and mitigating the risk of COVID-19 associated pulmonary aspergillosis. European Respiratory Journal 2020;56(4):2002554. doi: 10.1183/13993003.02554-2020

48. Zhu X, Ge Y, Wu T, et al. Co-infection with respiratory pathogens among COVID-2019 cases. Virus Res 2020;285:198005. doi: 10.1016/j.virusres.2020.198005 [published Online First: 2020/05/15]

49. Rothe K, Feihl S, Schneider J, et al. Rates of bacterial co-infections and antimicrobial use in COVID-19 patients: a retrospective cohort study in light of antibiotic stewardship. Eur J 
medRxiv preprint doi: https://doi.org/10.1101/2021.09.02.21262599; this version posted September 7, 2021. The copyright holder for this preprint (which was not certified by peer review) is the author/funder, who has granted medRxiv a license to display the preprint in perpetuity.

All rights reserved. No reuse allowed without permission.

Clin Microbiol Infect Dis 2021;40(4):859-69. doi: 10.1007/s10096-020-04063-8 [published Online First: 2020/11/04]

50. Akbar AN, Gilroy DW. Aging immunity may exacerbate COVID-19. Science 2020;369(6501):256-57. doi: 10.1126/science.abb0762

51. Rasyid H, Sangkereng A, Harjianti $T$, et al. Impact of age to ferritin and neutrophillymphocyte ratio as biomarkers for intensive care requirement and mortality risk in COVID-19 patients in Makassar, Indonesia. Physiological Reports 2021;9(10):e14876. doi: https://doi.org/10.14814/phy2.14876

52. Feld J, Tremblay D, Thibaud S, et al. Ferritin levels in patients with COVID-19: A poor predictor of mortality and hemophagocytic lymphohistiocytosis. International Journal of Laboratory Hematology 2020;42(6):773-79. doi: https://doi.org/10.1111/ijlh.13309

53. Prochaska JH, Frank B, Nagler M, et al. Age-related diagnostic value of D-dimer testing and the role of inflammation in patients with suspected deep vein thrombosis. Scientific Reports 2017;7(1):4591. doi: 10.1038/s41598-017-04843-x

54. Mejias NH, Martinez CC, Stephens ME, et al. Contribution of the inflammasome to inflammaging. Journal of inflammation (London, England) 2018;15:23. doi: 10.1186/s12950-018-0198-3 [published Online First: 2018/11/27] 


\section{Figure Legends}

\section{Figure 1 - STrengthening the Reporting of OBservational studies in Epidemiology) Diagram} 1063 COVID-19 patients were hospitalised at the Zan Mitrev Clinic between June 2020 and June 2021. The observed overall mortality rate was $24.3 \%(N=258)$; of these mortality cases, $N=43(17 \%)$ succumbed to their disease within 72 hours of admission, and $\mathrm{N}=25$ patients were discharged in that time frame following conservative treatment for mild symptoms.

COVID-19, coronavirus disease 2019; RT-PCR, reverse transcription-polymerase chain reaction test.

\section{Figure 2 - Post-Acute Sequelae of COVID-19 (PASC)}

Panel A shows pie charts indicating the distribution of reported PASC among the mild, moderate, and severe subgroups. (\%) Numbers correspond to individuals who reported said PASC; colours indicate respective PASC

Panel B depicts a dot plot graph visualising the distribution of \% Number of individuals reporting PASC according to clinical disease severity.

Panel C shows the contingency table comparing the proportion of mild- to moderate cases vs severe cases with PASC; numbers in bar represent the patient count, \% above the grey and red bar are the reported proportion of no PASC and PASC, respectively.

\section{Figure 3 - Biochemical parameters at admission and follow-up}

Graphs show scatter plots of selected biomarkers (Table 3) stratified according to clinical severity and time. Subgroups at admission and follow-up are represented by grey and red, respectively; colour shading indicates clinical severity. The follow-up measurements were compared to reference values generated from a healthy control cohort.

Effect sizes were determined using the Mann-Whitney test, and the median difference $(\Delta)$ in comparison to the median reference value (horizontal dashed line) (Table 3) is shown above the subgroups. Significance levels between the follow-up subgroups and the reference values are shown; significance is visualized by 
medRxiv preprint doi: https://doi.org/10.1101/2021.09.02.21262599; this version posted September 7, 2021. The copyright holder for this preprint (which was not certified by peer review) is the author/funder, who has granted medRxiv a license to display the preprint in perpetuity. All rights reserved. No reuse allowed without permission.

asterisks ${ }^{*}<0.05,{ }^{* *}<0.01,{ }^{* * *}<0.001$, and ${ }^{* * * *}<0.0001$. CRP, C-reactive protein; IL6, interleukin-6; LDH, lactate dehydrogenase, SII, systemic immune-inflammation index; NLR, neutrophil-to-lymphocyte ratio. 
medRxiv preprint doi: https://doi.org/10.1101/2021.09.02.21262599; this version posted September 7, 2021. The copyright holder for this preprint (which was not certified by peer review) is the author/funder, who has granted medRxiv a license to display the preprint in perpetuity.

All rights reserved. No reuse allowed without permission.

\section{Supplementary Figure Legends}

\section{Supplementary Figure 1 - Geographical location of study cohort}

Panel A depicts the geographical location of our study cohort. The percent (\%) above the location name represents the proportion of patients; increasing circle size corresponds to number magnitude.

\section{Supplementary Figure 2 - Detected bacterial isolates in the study cohort}

The pie chart depicts the distribution of bacterial isolates among the study cohort. (\%) Numbers correspond to individuals in which said isolate was detected; colours indicate individual isolates. 
medRxiv preprint doi: https://doi.org/10.1101/2021.09.02.21262599; this version posted September 7, 2021. The copyright holder for this preprint (which was not certified by peer review) is the author/funder, who has granted medRxiv a license to display the preprint in perpetuity.

All rights reserved. No reuse allowed without permission.

\section{Tables}

Table 1 - Patient Demographics and Clinical Characteristics

\begin{tabular}{|c|c|c|c|c|c|}
\hline & $\begin{array}{l}\text { Full Cohort } \\
(\mathrm{N}=168)\end{array}$ & $\begin{array}{l}\text { Mild } \\
(\mathrm{N}=38,23 \%)\end{array}$ & $\begin{array}{l}\text { Moderate } \\
(\mathrm{N}=29,17 \%)\end{array}$ & $\begin{array}{l}\text { Severe } \\
(N=101,60 \%)\end{array}$ & $P$-value \\
\hline \multicolumn{6}{|l|}{ Demographics } \\
\hline Age (years) & $59(50-68)$ & $55(48-67)$ & $60(49-66)$ & $60(51-68)$ & 0.3503 \\
\hline Age $>65$ years & $54(32)$ & $11(29)$ & $7(24)$ & $36(35)$ & 0.4499 \\
\hline Male Sex & $127(75)$ & $31(82)$ & $18(62)$ & $78(76)$ & 0.1526 \\
\hline \multicolumn{6}{|l|}{ Comorbidities } \\
\hline Hypertension & $80(48)$ & $13(34)$ & $16(55)$ & $51(50)$ & 0.1543 \\
\hline Hyperlipidaemia & $20(12)$ & $3(8)$ & $4(14)$ & $13(13)$ & 0.7384 \\
\hline Type II Diabetes & & $6(16)$ & $6(21)$ & $18(18)$ & 0.8740 \\
\hline Obesity & $16(10)$ & $2(5)$ & $4(1$ & $10(10)$ & 0.4890 \\
\hline Pulmonary disease ${ }^{1}$ & $8(5)$ & $0(0)$ & $3(10)$ & $5(5)$ & 0.1422 \\
\hline Cardiovascular disease $^{2}$ & $9(5)$ & $2(5)$ & $3(10)$ & $4(4)$ & 0.4041 \\
\hline Renal insufficiency ${ }^{3}$ & $2(1)$ & $1(3)$ & $1(2)$ & $1(1)$ & 0.6137 \\
\hline Hypothyroidism & $4(2)$ & $1(3)$ & $2(7)$ & $1(1)$ & 0.1831 \\
\hline Autoimmune disease ${ }^{4}$ & $3(2)$ & $1(3)$ & $1(2)$ & $1(1)$ & 0.6188 \\
\hline No comorbidity & $59(35)$ & $16(42)$ & $8(28)$ & $35(35)$ & 0.4617 \\
\hline Other & $25(15)$ & $9(24)$ & $6(21)$ & $10(10)$ & 0.0991 \\
\hline
\end{tabular}

Data are presented as median (interquartile range) or $N(\%)$.

${ }^{1}$ Chronic obstructive pulmonary disease (COPD); chronic bronchitis; bronchopneumonia.

${ }^{2}$ Coronary disease, carotid artery disease, atrial fibrillation, chronic atrial fibrillation, congestive heart failure, post CABG, stent implant, peripheral artery disease (PAD)

${ }^{3}$ Chronic kidney disease, hydronephrosis.

${ }^{4}$ Hashimoto's disease, rheumatoid arthritis. 
medRxiv preprint doi: https://doi.org/10.1101/2021.09.02.21262599; this version posted September 7, 2021. The copyright holder for this preprint (which was not certified by peer review) is the author/funder, who has granted medRxiv a license to display the preprint in perpetuity.

All rights reserved. No reuse allowed without permission.

Table 2 - Clinical course and clinical practice

\begin{tabular}{|c|c|c|c|c|c|}
\hline & $\begin{array}{l}\text { Full Cohort } \\
(\mathrm{N}=168)\end{array}$ & $\begin{array}{l}\text { Mild } \\
(\mathrm{N}=38,23 \%)\end{array}$ & $\begin{array}{l}\text { Moderate } \\
(\mathrm{N}=29,17 \%)\end{array}$ & $\begin{array}{l}\text { Severe } \\
(\mathrm{N}=101, \\
60 \%)\end{array}$ & P-value \\
\hline \multicolumn{6}{|l|}{ Peripheral Saturation } \\
\hline $\mathrm{SpO}_{2} \%$ at ambient pressure & $92(88-95)$ & $96(95-97)$ & $95(94-95)$ & $88(80-92)$ & $<0.0001$ \\
\hline $\mathrm{SpO}_{2} \%$ after/with oxygen supplementation ${ }^{1}$ & $93(91-95)$ & $96(95-97)$ & $95(94-97)$ & $92(90-93)$ & $<0.0001$ \\
\hline \multicolumn{6}{|l|}{ Oxygen support } \\
\hline Low-flow $\mathrm{O}_{2}$ support ${ }^{1}$ & $90(54)$ & $0(0)$ & $27(93)$ & $77(76)$ & $<0.0001$ \\
\hline Noninvasive mechanical ventilation (CPAP) ${ }^{1}$ & $22(15)$ & $0(0)$ & $3(10)$ & $19(19)$ & 0.0122 \\
\hline Mechanical Respiratory support ${ }^{2}$ & $19(11)$ & $3(8)$ & $4(14)$ & $12(12)$ & 0.7214 \\
\hline Duration (h) & $\begin{array}{l}13.0 \\
(2.0-121.0)\end{array}$ & $\begin{array}{l}1.0 \\
(1.0\end{array}$ & $\begin{array}{l}1.5 \\
(1.0-182.8)\end{array}$ & $\begin{array}{l}20.5 \\
(10.0-169.8)\end{array}$ & 0.0788 \\
\hline \multicolumn{6}{|l|}{ Secondary Infections } \\
\hline Bacterial & $58(35)$ & $12(32)$ & $11(38)$ & $35(35)$ & 0.8627 \\
\hline Fungal & $57(34)$ & $9(24)$ & $5(17)$ & $43(43)$ & 0.0126 \\
\hline Hospital stay (days) & $11(9-20)$ & $9(8-11)$ & $11(9-21)$ & $13(10-21)$ & 0.0088 \\
\hline Clinical follow-up (days) & $53(30-105)$ & $45(30-107)$ & $59(29-110)$ & $53(31-102)$ & 0.9792 \\
\hline
\end{tabular}

Data are presented as median (interquartile range) or $N(\%)$. SpO2 \%, oxygen saturation \%, CPAP, continuous positive airway pressure; CRRT, continuous renal replacement therapy; oXiris, filter for extracorporeal blood purification.

${ }^{1}$ Refers to patients who were already on oxygen support at admission OR received oxygen support within the first 24 hours of admission.

${ }^{2}$ Intubation at any point during hospitalisation. 
medRxiv preprint doi: https://doi.org/10.1101/2021.09.02.21262599; this version posted September 7, 2021. The copyright holder for this preprint (which was not certified by peer review) is the author/funder, who has granted medRxiv a license to display the preprint in perpetuity.

All rights reserved. No reuse allowed without permission.

Table 3: Blood biochemistry at follow-up

\begin{tabular}{|c|c|c|c|c|}
\hline $\begin{array}{l}\text { Biochemical Parameter } \\
\text { Reference Value }\end{array}$ & & $\begin{array}{l}\text { Mild } \\
(\mathrm{N}=38,23 \%)\end{array}$ & $\begin{array}{l}\text { Moderate } \\
(\mathrm{N}=29,17 \%)\end{array}$ & $\begin{array}{l}\text { Severe } \\
(\mathrm{N}=101,60 \%)\end{array}$ \\
\hline \multirow{2}{*}{$\begin{array}{l}\text { WBC count }\left(\times 10^{\wedge} 3 / \mu \mathrm{L}\right) \\
6.6(5.6-8.0)\end{array}$} & Follow-up & $6.4(5.4-7.5)$ & $6.5(5.1-7.5)$ & $7.2(6.2-8.8)$ \\
\hline & Difference ${ }^{\#}$ & $-0.2[95 \% \mathrm{Cl}-0.8$ to 0.4$]$ & $-0.1[95 \% \mathrm{Cl}-1.0$ to 0.3$]$ & $0.63[95 \% \mathrm{Cl} 0.3 \text { to } 1.1]^{*}$ \\
\hline \multirow{2}{*}{$\begin{array}{l}\text { CRP }(\mathrm{mg} / \mathrm{l}) \\
1.8(0.8-4.8)\end{array}$} & Follow-up & $2.6(0.7-8.6)$ & $4.1(0.9-16.6)$ & $5.7(2.5-18.9)$ \\
\hline & Difference ${ }^{\#}$ & $0.8[95 \% \mathrm{Cl}-0.5$ to 1.6$]$ & $2.3[95 \% \mathrm{Cl} 0.0$ to 4.5$]$ & $3.9[95 \% \mathrm{Cl} 2.0$ to 5.3$]$ * \\
\hline \multirow{2}{*}{$\begin{array}{l}\mathrm{LDH}(\mathrm{U} / \mathrm{l}) \\
170(149-195)\end{array}$} & Follow-up & $185(167-236)$ & $251(182-267)$ & $243(206-346)$ \\
\hline & Difference ${ }^{\#}$ & $15[95 \% \mathrm{Cl}-4.0$ to 46$]$ & $72[95 \% \mathrm{Cl} 28 \text { to } 90]^{*}$ & $74[95 \% \mathrm{Cl} 57 \text { to } 112]^{*}$ \\
\hline \multirow{2}{*}{$\begin{array}{l}\mathrm{RBC} \text { count }\left(\times 10^{\wedge} 5 / \mu \mathrm{L}\right) \\
4.9 \pm 0.5\end{array}$} & Follow-up & $4.7 \pm 0.7$ & $4.7 \pm 0.7$ & $4.5 \pm 0.6$ \\
\hline & Difference ${ }^{\#}$ & $0.1[95 \% \mathrm{Cl}-0.04$ to 0.3$]$ & $0.2[95 \% \mathrm{Cl}-0.00$ to 0.4$]$ & $0.4[95 \% \mathrm{Cl} 0.2 \text { to } 0.5]^{*}$ \\
\hline \multirow{2}{*}{$\begin{array}{l}\text { Neutrophils \% } \\
56.4 \pm 10.1\end{array}$} & Follow-up & $59.5 \pm 10.5$ & $57.0 \pm 10.0$ & $60.1 \pm 12.3$ \\
\hline & Difference ${ }^{\#}$ & $3.1[95 \% \mathrm{Cl}-0.3$ to 6.6$]$ & $0.6[95 \% \mathrm{Cl}-3.2$ to 4.4$]$ & $3.7[95 \% \mathrm{Cl} 1.4 \text { to } 6.0]^{*}$ \\
\hline \multirow{2}{*}{$\begin{array}{l}\text { Lymphocytes \% } \\
32.8(26.1-38.1)\end{array}$} & Follow-up & $30.3(22.2-36.6)$ & $31.2(27.1-39.5)$ & $28.5(21.4-38.6)$ \\
\hline & Difference ${ }^{\#}$ & $-2.5[95 \% \mathrm{Cl}-5.6$ to 0.7$]$ & $-1.6[95 \% \mathrm{Cl}-2.8$ to 4.1$]$ & $-4.3[95 \% \mathrm{Cl}-5.0$ to -0.3$]$ * \\
\hline \multirow{2}{*}{$\begin{array}{l}\text { NLR } \\
1.7(1.3-2.4)\end{array}$} & Follow-up & $1.9(1.4-2.9)$ & $1.9(1.3-2.3)$ & $2.1(1.3-3.2)$ \\
\hline & Difference ${ }^{\#}$ & $0.2[95 \% \mathrm{Cl}-0.03$ to 0.5$]$ & $0.2[95 \% \mathrm{Cl}-0.3$ to 0.3$]$ & $0.4[95 \% \mathrm{Cl} 0.06$ to 0.5$]$ * \\
\hline \multirow{2}{*}{$\begin{array}{l}\text { Platelet count }\left(\times 10^{\wedge} 3 /\right. \\
\mu L) 228(190-268)\end{array}$} & Follow-up & $247(201-278) \mathrm{C}$ & $236(192-285)$ & 247 (207-289) \\
\hline & Difference ${ }^{\#}$ & $19[95 \% \mathrm{Cl}-9$ to 32$]$ & 8 [95\% Cl -20 to 32] & $19[95 \% \mathrm{Cl} 7$ to 35$]$ * \\
\hline \multirow{2}{*}{$\begin{array}{l}\text { Monocytes \% } \\
8.2(6.9-9.7)\end{array}$} & Follow-up & $8.4(7.2-10.3)$ & $8.2(7.0-9.5)$ & $8.0(6.4-9.5)$ \\
\hline & Difference ${ }^{\#}$ & $0.2[95 \% \mathrm{Cl}-0.7$ to 0.9$]$ & $0.04[95 \% \mathrm{Cl}-0.9$ to 0.8$]$ & $-0.2[95 \% \mathrm{Cl}-0.9$ to 0.04$]$ \\
\hline \multirow{2}{*}{$\begin{array}{l}\text { ALT }(U / I) \\
30(24-43)\end{array}$} & Follow-up & $36(27-49)$ & $34(27-43)$ & $39(29-47)$ \\
\hline & Difference ${ }^{\#}$ & $6[95 \% \mathrm{Cl}-1$ to 9$]$ & $4[95 \% \mathrm{Cl}-2$ to 9$]$ & $9[95 \% \mathrm{Cl} 3$ to 10$]$ * \\
\hline \multirow{2}{*}{$\begin{array}{l}\text { AST (U/I) } \\
23(20-27)\end{array}$} & Follow-up & $23(20-28)$ & $23(17-27)$ & $23(19-27)$ \\
\hline & Difference ${ }^{\#}$ & $0[95 \% \mathrm{Cl}-2$ to 3$]$ & $-1[95 \% \mathrm{Cl}-4$ to 2$]$ & $0[95 \% \mathrm{Cl}-2$ to 1$]$ \\
\hline \multirow{2}{*}{$\begin{array}{l}\text { Basophils, \% } \\
0.40(0.20-0.50)\end{array}$} & Follow-up & $0.40(0.26-0.56)$ & $0.40(0.30-0.50)$ & $0.35(0.29-0.47)$ \\
\hline & Difference ${ }^{\#}$ & $0.0[95 \% \mathrm{Cl} 0.0$ to 0.10$]$ & $0.0[95 \% \mathrm{Cl} 0.0$ to 0.1$]$ & $-0.05[95 \% \mathrm{Cl}-0.03$ to 0.04$]$ \\
\hline \multirow{2}{*}{$\begin{array}{l}\text { Eosinophil, \% } \\
2.2(1.3-3.3)\end{array}$} & Follow-up & $1.8(1.1-2.9)$ & $1.6(1.0-2.4)$ & $1.8(0.9-2.8)$ \\
\hline & Difference ${ }^{\#}$ & $-0.4[95 \% \mathrm{Cl}-0.8$ to 0.2$]$ & $-0.6[95 \% \mathrm{Cl}-1.0$ to -0.06$]$ & $-0.5[95 \% \mathrm{Cl}-0.8$ to -0.1$]$ \\
\hline \multirow{2}{*}{$\begin{array}{l}\text { Haemoglobin }(\mathrm{g} / \mathrm{dl}) \\
14.3(13.2-15.3)\end{array}$} & Follow-up & $13.8(12.5-14.7)$ & $13.8(11.7-14.4)$ & $13.2(11.8-14.3)$ \\
\hline & Difference ${ }^{\#}$ & $-0.5[95 \% \mathrm{Cl}-1.1$ to 0.0$]$ & $-0.5[95 \% \mathrm{Cl}-1.5$ to -0.3$]$ & $-1.1[95 \% \mathrm{Cl}-1.5$ to -0.8 \\
\hline \multirow{2}{*}{$\begin{array}{l}\text { D-dimer }(\mathrm{ng} / \mathrm{mL}) \\
305.0(192.5-475.0)\end{array}$} & Follow-up & $315(190.0-455)$ & $450(280-1220)$ & $600(283-1168)$ \\
\hline & Difference ${ }^{\#}$ & $10[95 \% \mathrm{Cl}-70$ to 70$]$ & $145[95 \% \mathrm{Cl} 0.0$ to 270$]$ * & $295[95 \% \mathrm{Cl} 120$ to 410$]$ * \\
\hline \multirow{2}{*}{$\begin{array}{l}\text { Haematocrit } \\
40.9(38.5-43.4)\end{array}$} & Follow-up & $39.7(36.5-42.8)$ & $40.4(36.3-42.6)$ & $38.6(35.0-41.8)$ \\
\hline & Difference ${ }^{\#}$ & $-1.2[95 \% \mathrm{Cl}-2.5$ to 0.4$]$ & $-0.5[95 \% \mathrm{Cl}-2.7$ to 0.5$]$ & $-2.3[95 \% \mathrm{Cl}-3.3$ to -1.3$]{ }^{*}$ \\
\hline \multirow{2}{*}{$\begin{array}{l}\text { Fibrinogen }(\mathrm{g} / \mathrm{l}) \\
2.8(2.5-3.3)\end{array}$} & Follow-up & $2.9(2.7-3.6)$ & $2.8(2.3-3.2)$ & $3.1(2.7-4.3)$ \\
\hline & Difference ${ }^{\#}$ & $0.1[95 \% \mathrm{Cl}-0.2$ to 0.6$]$ & $0.1[95 \% \mathrm{Cl}-0.3$ to 0.5$]$ & $0.3[95 \% \mathrm{Cl} 0.05$ to 0.8$]$ \\
\hline
\end{tabular}

Reference values are shown under the biochemical parameter name in the first column. Reference values were based on asymptomatic patients performing routine laboratory check-up $(\mathrm{N}=628)$. Data are presented as median (interquartile range) or mean \pm (standard deviation). Deviation from reference values is shown as the median/mean difference $+95 \%$ confidence interval. Asterisk * indicates a $p$-value $<0.05$.

CRP, C-reactive protein; IL6, interleukin-6; ALT, alanine aminotransferase; AST, aspartate aminotransferase, LDH, lactate dehydrogenase, WBC, white blood cell count; RBC, red blood cell count; SII, systemic immune-inflammation index; NLR, neutrophilto-lymphocyte ratio. 
medRxiv preprint doi: https://doi.org/10.1101/2021.09.02.21262599; this version posted September 7, 2021. The copyright holder for this preprint (which was not certified by peer review) is the author/funder, who has granted medRxiv a license to display the preprint in perpetuity.

All rights reserved. No reuse allowed without permission.

Table 3: Blood biochemistry at follow-up (continued)

\begin{tabular}{|c|c|c|c|c|}
\hline $\begin{array}{l}\text { Ferritin }(\mathrm{ng} / \mathrm{ml}) \\
88(38-200)\end{array}$ & $\begin{array}{l}\text { Follow-up } \\
\text { Difference }\end{array}$ & $\begin{array}{l}226(78-393) \\
138 \text { [95\% Cl }-20 \text { to } 229]\end{array}$ & $\begin{array}{l}257(97-425) \\
170[95 \% \mathrm{Cl}-44 \text { to } 241]\end{array}$ & $\begin{array}{l}432(170-916) \\
344[95 \% \mathrm{Cl} 141 \text { to } 498] \text { * }\end{array}$ \\
\hline $\begin{array}{l}\text { IL-6 (pg/ml) } \\
2.8(1.4-3.6)\end{array}$ & $\begin{array}{l}\text { Follow-up } \\
\text { Difference }\end{array}$ & $\begin{array}{l}2.0(0.7-8.7) \\
-0.8[95 \% \mathrm{Cl}-1.7 \text { to } 4.6]\end{array}$ & $\begin{array}{l}3.7(0.5-216.6) \\
0.9[95 \% \mathrm{Cl}-2.2 \text { to } 10.0]\end{array}$ & $\begin{array}{l}5.1(1.7-28.9) \\
2.3[95 \% \mathrm{Cl} 0.4 \text { to } 7.4] \text { * }\end{array}$ \\
\hline $\begin{array}{l}\text { SII } \\
398(281-589)\end{array}$ & $\begin{array}{l}\text { Follow-up } \\
\text { Difference }\end{array}$ & $\begin{array}{l}453(313-693) \\
55.5[95 \% \mathrm{Cl}-22.2 \text { to } 144]\end{array}$ & $\begin{array}{l}428(254-622) \\
29.8[95 \% \mathrm{Cl}-61.6 \text { to } 115]\end{array}$ & $\begin{array}{l}512(308-855) \\
114[95 \% \mathrm{Cl} 28.7-147] \text { * }\end{array}$ \\
\hline $\begin{array}{l}\text { Urea }(\mathrm{mmol} / \mathrm{L}) \\
4.5(3.7-5.6)\end{array}$ & $\begin{array}{l}\text { Follow-up } \\
\text { Difference }\end{array}$ & $\begin{array}{l}4.9(3.6-6.3) \\
0.4[95 \% \mathrm{Cl}-0.2-0.9]\end{array}$ & $\begin{array}{l}4.3(3.6-5.3) \\
-0.2[95 \% \mathrm{Cl}-0.6 \text { to } 0.5]\end{array}$ & $\begin{array}{l}4.8(3.6-5.7) \\
0.3[95 \% \mathrm{Cl}-0.2 \text { to } 0.5]\end{array}$ \\
\hline $\begin{array}{l}\text { Creatinine }(\mu \mathrm{mol} / \mathrm{L}) \\
76.2(65.2-87.6)\end{array}$ & $\begin{array}{l}\text { Follow-up } \\
\text { Difference }\end{array}$ & $\begin{array}{l}77.4(65.7-87.2) \\
1.3[95 \% \mathrm{Cl}-5.7-6.1]\end{array}$ & $\begin{array}{l}67.3(55.6-84.2) \\
-8.9[95 \% \mathrm{Cl}-14.3-0.4]\end{array}$ & $\begin{array}{l}67.0(55.0-81.5) \\
-9.1[95 \% \mathrm{Cl}-12.0-4.0]\end{array}$ \\
\hline
\end{tabular}

Reference values are shown under the biochemical parameter name in the first column. Reference values were based on asymptomatic patients performing routine laboratory check-up $(\mathrm{N}=628)$. Data are presented as median (interquartile range) or mean \pm (standard deviation). Deviation from reference values is shown as the median/mean difference $+95 \%$ confidence interval. Asterisk * indicates a p-value $<0.05$.

CRP, C-reactive protein; IL6, interleukin-6; ALT, alanine aminotransferase; AST, aspartate aminotransferase, LDH, lactate dehydrogenase, WBC, white blood cell count; RBC, red blood cell count; SII, systemíc immune-inflammation index; NLR, neutrophilto-lymphocyte ratio. 


\section{Figure 1}

\section{STROBE Diagram}

\section{Inclusion Criteria}

- Admitted between June 2020 and June 2021

$\bullet \geq 18$ years

- Confirmed COVID-19 diagnosis via RT-PCR
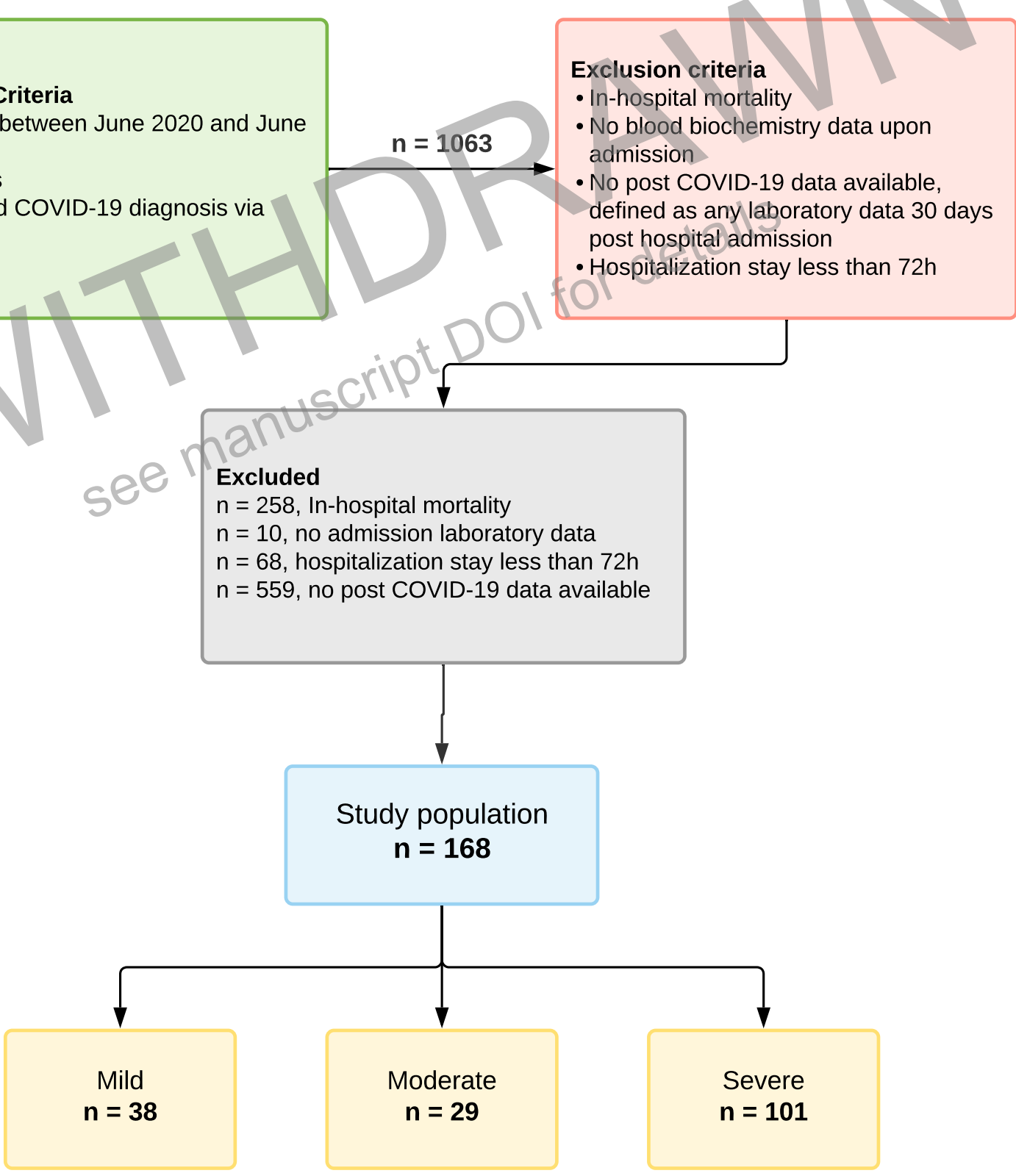
A

Post-Acute Sequelae COVID-19

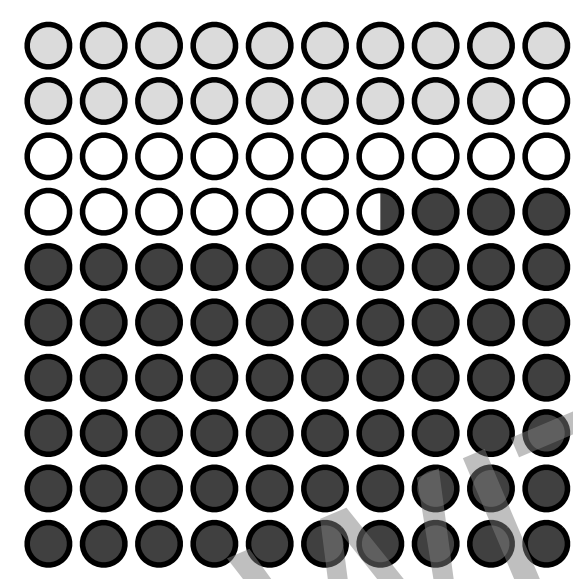

Total $=96$

$\square 18.75 \% 18$ Mild

$17.71 \% 17$ Moderate

63.54\% 61 Severe

C

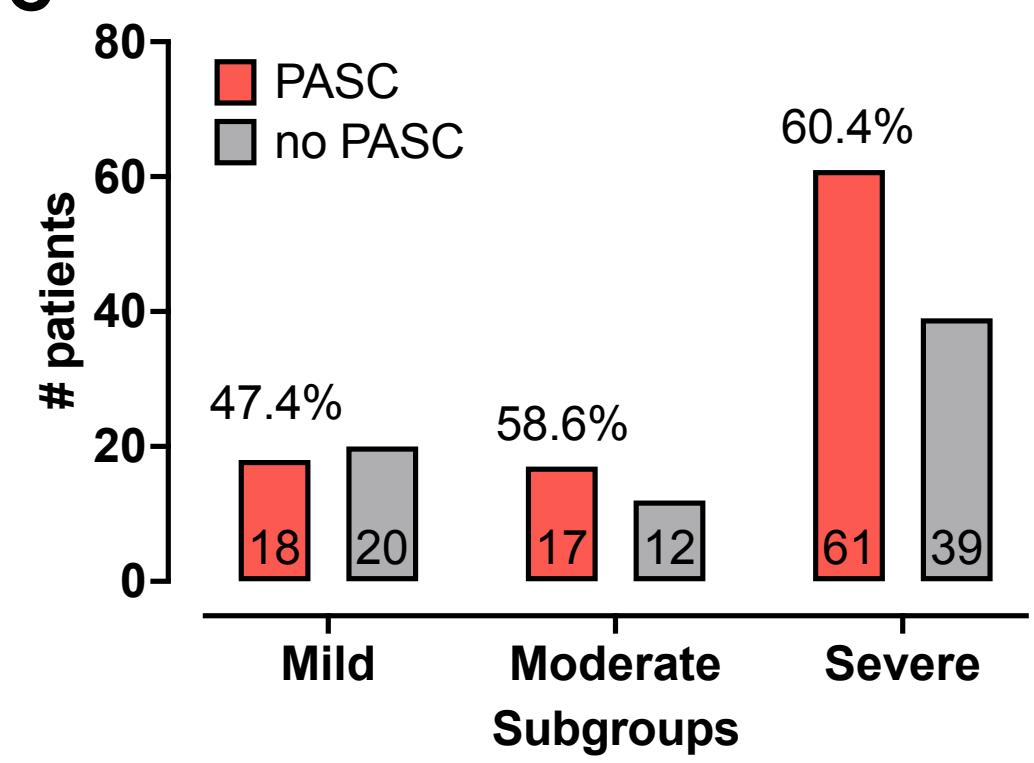

B

Mild

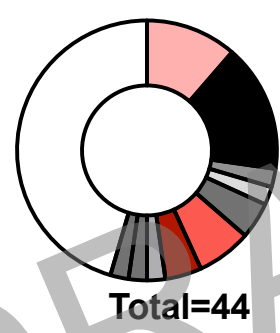

$11.36 \% 5$ Difficulty breathing or shortness of breath

$15.91 \% 7$ Tiredness or fatigue

$2.33 \% 1$ Difficulty thinking or concentrating

$4.55 \% 2$ Cough

$6.82 \% 3$ Chest or stomach pain

$4.65 \% 2$ Fast-beating or pounding heart

$2.27 \% 1$ Joint or muscle pain

$2.33 \% 1$ Dizziness on standing

45.45\% 20 No clinical symptoms

$2.27 \% 1$ Symptoms that get worse after physical or mental activities $2.27 \% 1$ Mood changes

Moderate

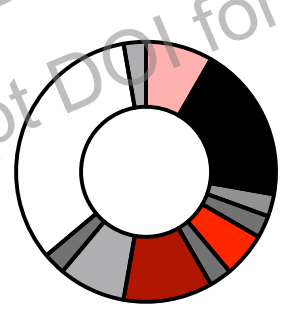

Total $=36$ $+2115$

$\square$ 8.33\% 3 Difficulty breathing or shortness of breath

$19.44 \% 7$ Tiredness or fatigue

$\square 2.78 \% 1$ Cough

$\square .56 \% 2$ Chest or stomach pain

$\square 4.65 \% 2$ Fast-beating or pounding heart

$\square 2.78 \% 1$ Headache

$\square 8.33 \% 3$ Joint or muscle pain

$\square 2.70 \% 1$ Dizziness on standing

$\square 33.33 \% 12$ No clinical symptoms

$2.78 \% 1$ Symptoms that get worse after physical or mental activities $\square 2.78 \% 1$ Not recorded

Severe

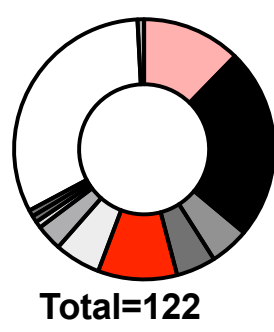

$4.92 \% 6$ Cough

9.84\% 12 Chest or stomach pain

$12.30 \% 15$ Difficulty breathing or shortness of breath

$23.77 \% 29$ Tiredness or fatigue

$4.92 \% 6$ Symptoms that get worse after physical or mental activities

$\square 0.82 \% 1$ Mood changes

$\square 0.82 \% 1$ Not recorded

$3.28 \% 4$ Joint or muscle pain

$31.97 \% 39$ No clinical symptoms

$5.74 \% 7$ Fast-beating or pounding heart

$\square 0.82 \% 1$ Fever

$\square 0.82 \% 1$ Dizziness on standing 
